\title{
STRATEGI PENGEMBANGAN AGRIBISNIS AYAM RAS PETELUR PADA CV. BINTANI POULTRY SHOP KENDARI
}

\author{
Musram Abadi ${ }^{1}$, Siti Aida Taridala ${ }^{2}$,La Ode Nafiu ${ }^{1}$ \\ ${ }^{1}$ Fakultas Peternakan Universitas Halu Oleo Jl. HEA. Mokodompit Kendari \\ ${ }^{2}$ Fakultas Pertanian Universitas Halu Oleo Jl. HEA Mokodompit Kendari \\ Email:musram.abadi8@gmail.com
}

\begin{abstract}
Abstrak
Penelitian ini bertujuan menganalisis dan mengidentifikasi faktor-faktor pendukung dan penghambat, menyusun strategi pengembangan agribisnis, peternakan ayam ras petelur pada perusahaan CV. Bintani Poultry Shop Kendari. Penelitian dilaksanakan pada tahun 2012. Variabel penelitian adalah (a) karakterisitik usaha peternakan ayam ras petelur dan (b) kekuatan, kelemahan, ancaman dan peluang. Analisis dari aspek strategi pengembangan agribisnis menggunakan analisis SWOT dan analisis QSPM. Hasil penelitian menunjukkan bahwa strategi untuk meningkatkan kapasitas produksi memiliki skor 6,146, peningkatan kualitas dan jumlah karyawan dengan skor 5,375. Sementara itu pemanfaatan teknologi dalam pemeliharaan ayam ras petelur memiliki skor 5,303 dan pengembangan usaha jenis ternak lainnya 4,220.
\end{abstract}

Kata Kunci : Agribisnis, Ayam Ras Petelur dan Strategi Pengembangan.

\begin{abstract}
The research was conducted to analyze and identify supporting and inhibiting factors, arranging layer farm agribusiness development strategy on CV Bintani Poultry Shop Kendari. This research was held on 2012. The research variables were (a) layer farm business characteristic and (b) strength, weakness, threat, and opportunity. The agribusiness development strategy aspect analysis was using SWOT and QSPM analysis. Research result showed that production capacity increasing strategy and quality increasing and worker quantity were scored 6,146, and 5,375 respectively. Meanwhile technology application on layer farming practice and others livestock business development were scored 5,303 and 4,220 respectively.
\end{abstract}

Key words: Agribusiness, Layer Farm, Development Strategy 


\section{PENDAHULUAN}

Agribisnis ayam ras petelur di Indonesia memiliki prospek yang baik untuk dikembangkan, terutama bila ditinjau dari aspek kebutuhan masyarakat akan gizi. Sesuai standar nasional, konsumsi protein per hari per kapita ditetapkan 55 gram yang terdiri dari $80 \%$ protein nabati dan $20 \%$ protein hewani. Pemenuhan gizi ini, khususnya protein hewani dapat diperoleh dari protein telur. Dengan demikian, usaha agribisnis ayam ras petelur memiliki potensi yang baik untuk dikembangkan guna memenuhi gizi masyarakat. Peternakan rakyat di Indonesia yang bergerak dalam bidang usaha ayam ras petelur mencapai $82,4 \%$, sehingga usaha peternakan rakyat perlu terus didorong untuk mencapai kesejahteraan peternak, sebagai sumber penerimaan dan pendapatan asli daerah (PAD) melalui retribusi ternak maupun sebagai pajak usaha (Saragih, 2001).

Kajian dari sisi permintaan, saat ini produksi telur ayam ras baru mampu mencukupi kebutuhan pasar dalam negeri sebesar $65 \%$. Sisanya dipenuhi telur ayam kampung, itik dan puyuh. Iklim perdagangan global yang mulai terasa saat ini, semakin memungkinkan produk telur ayam ras dari Indonesia untuk masuk ke pasar luar negeri, mengingat produk ayam ras daging dan telurnya bersifat elastis terhadap perubahan pendapatan per kapita per tahun dari suatu negara (Abidin, 2003).

Provinsi Sulawesi Tenggara merupakan salah satu daerah di Indonesia yang cukup potensial sebagai sentra pengembangan usaha agribisnis ayam ras petelur, karena memiliki potensi pasar yang cukup besar, hal ini dapat dilihat dari jumlah penduduknya pada tahun 2010 sebanyak 2.232.586 jiwa yang tersebar di 12 kabupaten/kota.
Populasi ternak ayam ras petelur tahun 2010 sebanyak $1.413 .782 \mathrm{~kg}$ dengan rata-rata konsumsi telurnya 0,59 $\mathrm{kg} / \mathrm{kapita} / \mathrm{tahun}$ (Dinas Pertanian Provinsi Sultra, 2010). Khusus di Kota Kendari, populasi ternak ayam ras petelur pada tahun 2010 sebanyak $155.970 \mathrm{~kg}$ dengan jumlah penduduk Kota Kendari tahun 2010 sebanyak 289.966 jiwa (Dinas Pertanian Provinsi Sultra, 2010).

Untuk konsumsi rumah tangga, telur ayam ras merupakan jenis yang paling banyak digunakan oleh masyarakat karena selain murah harganya, ukuran telur ayam ras juga lebih besar dibanding telur ayam kampung, itik dan puyuh. Konsumen rumah tangga dan industri makanan umumnya memilih telur ayam yang berukuran besar karena dirasa lebih efisien sehingga pilihannya jatuh pada telur ayam ras (Widjaja $\mathrm{K}$ dan Abdullah S, 2003). Data perbandingan tingkat konsumsi per kapita per tahun berbagai jenis telur Kota Kendari tahun 2010 yaitu (1) ayam ras petelur sebesar 6,54 $\mathrm{kg} / \mathrm{kapita} / \mathrm{tahun}$; (2) telur ayam buras sebesar 2,08 kg/kapita/tahun; dan (3) telur itik sebesar $1,04 \mathrm{~kg} / \mathrm{kapita} / \mathrm{tahun}$. Hal ini menunjukkan bahwa masyarakat Kota Kendari lebih memilih telur ayam ras petelur untuk dikonsumsi (Dinas Pertanian, Perkebunan, Peternakan dan Kehutanan Kota Kendari, 2010).

Oleh karena itu, agribisnis ayam ras petelur mempunyai posisi strategis dalam meningkatkan kualitas sumberdaya manusia melalui penyediaan protein hewani dan meningkatkan kesejahteraan masyarakat peternak. Cahyono (1994), menyatakan bahwa pengembangan usaha ayam ras petelur memiliki prospek bisnis menguntungkan, karena permintaan dan harga yang cenderung selalu meningkat.

Dari sekian banyak peluang yang ada, terdapat beberapa kendala dan 
hambatan seperti penyediaan bibit, pakan, obat-obatan/vaksin dan faktorfaktor produksi lainnya menyebabkan usaha agribisnis ayam ras petelur belum banyak dikembangkan oleh masyarakat, khususnya di Kota kendari. Ketidaktersediaannya faktor-faktor produksi vital seperti bibit, pakan dan obat-obatan/vaksin dengan harga yang stabil, menyebabkan para peternak sulit untuk melakukan prediksi dan perhitungan usaha yang menguntungkan.

Di Kota Kendari, perusahaan peternakan ayam ras petelur sudah cukup berkembang, hal ini ditandai dengan adanya perusahaan-perusahaan peternakan ayam ras petelur lainnya. Kendatipun demikian kondisi ini belum mampu memenuhi permintaan masyarakat akan telur. Ini tercatat sebagai peluang dalam pengembangan usaha peternakan ayam ras petelur. Selain dari kekuatan dan peluang yang disebutkan di atas juga terdapat beberapa ancaman besar bagi perusahaan CV. Bintani Poultry Shop Kendari adanya pendatang baru sebagai pemasok telur dengan harga yang relatif lebih murah. Selain itu berbagai kelemahan lain yang belum mampu diatasi dengan baik diantaranya adalah sumberdaya manusia (tenaga kerja), baik kualitas maupun kuantitasnya yang kurang mendukung dan fluktuasi harga input produksi.

Dari sekian banyak kekuatan dan kelemahan serta peluang dan ancaman yang ada, baru sebagian yang telah teridentifikasi. Untuk itu diperlukan penelitian lebih lanjut, khususnya evaluasi kelayakan dan strategi pengembangan agribisnis ayam ras petelur dari berbagai faktor-faktor kunci secara finansial serta yang menjadi kekuatan, kelemahan, peluang, dan ancaman usaha ayam ras petelur yang nantinya akan menghasilkan formula yang cocok untuk mengembangkan usaha telur ayam ras petelur khususnya di Kota Kendari. Hal ini dimaksudkan untuk dapat memberikan informasi pada para peternak maupun pemerintah dalam menentukan skala usaha yang menguntungkan dalam pengembangan usaha agribisnis ayam ras petelur seperti yang telah dilakukan oleh perusahaan CV. Bintani Poultry Shop Kendari.

\section{MATERI DAN METODE}

Penelitian ini dilaksanakan pada bulan Januari sampai dengan Februari 2012 di Kota Kendari. Kota Kendari merupakan daerah yang memiliki populasi ternak ayam ras petelur cukup besar dibandingkan dengan Kabupaten/Kota lainnya, tingkat konsumsi masyarakat tinggi terhadap telur serta merupakan Ibu Kota Provinsi yang menjadi konsumen telur terbesar di Sulawesi Tenggara.

Responden dalam penelitian ini adalah pemilik dan karyawan usaha peternakan ayam ras petelur pada $\mathrm{CV}$. Bintani Poultry Shop Kendari. Pemilihan kasus didasarkan pada beberapa pertimbangan, antara lain : (1) jumlah populasi ayam ras petelur yang dipelihara cukup tinggi; (2) usaha yang dijalankan relatif lebih lama dibandingkan usaha peternakan ayam ras petelur yang ada di Kota Kendari; (3) jumlah tenaga kerja yang diserap lebih banyak; dan (4) usaha yang dijalankan telah memiliki badan hukum.

Pengambilan data dilakukan dengan metode survey, Data pada penelitian ini terdiri dari data primer dan data sekunder. Data primer, yaitu data yang diperoleh dari wawancara langsung dengan para peternak ayam ras petelur dengan menggunakan daftar kuesioner, meliputi : identitas responden, jumlah ayam yang dipelihara, jumlah produksi, biaya produksi, penerimaan, jumlah tenaga 
kerja dan data penjualan telur. Sedangkan data sekunder, yaitu data kependudukan, data potensi wilayah dan data yang diperoleh dari perusahaan, meliputi : data harga bibit, harga pakan, data harga obatobatan/vaksin dan data harga telur, serta data lainnya yang dimiliki perusahaan yang dapat mendukung penelitian ini

\section{ANALISIS DATA}

Data yang diperoleh dalam penelitian ini ditabulasi, kemudian dianalisis dengan menggunakan alat analisis yang sesuai untuk menjawab permasalahan penelitian, yakni sebagai berikut :

1. Melakukan identifikasi faktor-faktor yang menjadi pendukung dan penghambat pengembangan agribisnis ayam ras petelur pada perusahaan CV. Bintani Poultry Shop Kendari, dianalisis secara deskriptif berdasarkan tanggapan responden.

2. Menganalisis strategi pengembangan agribisnis ayam ras petelur pada perusahan CV. Bintani Poultry Shop Kendari digunakan analisis SWOT.

a. Tahap analisis SWOT dilakukan dengan identifikasi faktor eksternal atau external factor evaluation (EFE) dan identifikasi faktor internal atau internal factor evaluation (IFE). Matriks IFE disusun berdasarkan kekuatan dan kelemahan yang dimiliki oleh peternakan ayam ras petelur, sedangkan matriks EFE disusun berdasarkan peluang dan ancaman yang dihadapi oleh peternakan ayam petelur.

b. Setelah diketahui nilai dari matriks IFE dan matriks EFE, maka tahap selanjutnya adalah melihat posisi peternakan ayam petelur berdasarkan nilai matriks IFE dan matriks EFE pada matriks IE (internal eksternal), yang digunakan untuk menentukan strategi pengembangan agribisnis ayam ras petelur, selanjutnya merumuskan alternatif strategi yang sesuai berdasarkan matriks SWOT.

c. Setelah diperoleh beberapa alternatif strategi melalui tahapan pencocokan yaitu dengan menggunakan matriks IE dan matriks SWOT, maka tahap akhir dari analisis formulasi strategi adalah pemilihan strategi yang terbaik. Metode yang digunakan untuk memutuskan strategi tersebut adalah Quantitative Strategic Planning Matriks (QSPM) (Rangkuti, 2006).

\section{HASIL DAN PEMBAHASAN}

\section{A. Identifikasi Pendukung dan Penghambat}

Berdasarkan hasil analisis faktor internal berupa kekuatan (strength), kelemahan (weaknes), peluang (opportunities), dan ancaman (threats), maka selanjutnya akan diidentifikasi faktor-faktor kunci yang merupakan kekuatan, kelemahan, peluang dan ancaman. Hasil identifikasi tersebut digunakan untuk menyusun matriks IFE (Internal Factor Evaluation) dan EFE (Eksternal Factor Evaluation).

\section{Analisis Matriks IFE}

Analisis internal perusahaan mengidentifikasi faktor-faktor kunci kekuatan (strength) dan kelemahan (weakness). Selanjutnya faktor-faktor strategis internal tersebut dimasukkan kedalam matriks IFE untuk mendapatkan total nilai yang dibobot. 
Nilai total yang dibobot merupakan hasil penjumlahan total dari perkalian bobot dan rating masing-masing faktor strategis internal.

Metode pembobotan dilakukan dengan menggunakan metode Paired Comparison sehingga diperoleh bobot masing-masing variabel. Pembobotan dan pemberian rating dilakukan oleh pemilik serta satu orang karyawan $\mathrm{CV}$. Bintani Poultry Shop Kendari. Demikian pula pemberian rating (peringkat), penentuan peringkat dilakukan oleh dua orang tersebut yang hasilnya merupakan rata-rata sehingga didapatkan nilai terboboti dari faktorfaktor tersebut. Untuk lebih jelasnya dapat dilihat pada Tabel 1.

Tabel 1. Matriks Internal Factor Evaluation (IFE)

\begin{tabular}{|c|c|}
\hline Faktor -Faktor Internal & Rata-Rata \\
\hline Kekuatan & Bobot x Rating \\
\hline 1. Ketersediaan faktor produksi secara kontinyu & 0,444 \\
\hline 2. Memiliki lahan yang luas & 0,447 \\
\hline 3. Kualitas telur yang segar & 0,250 \\
\hline 4. Hubungan perusahaan dengan pelanggan/konsumen & 0,356 \\
\hline 5. Citra perusahaan terhadap lembaga keuangan baik & 0,425 \\
\hline \multicolumn{2}{|l|}{ Kelemahan } \\
\hline 6. Kapasitas produksi memenuhi permintaan pelanggan & 0,136 \\
\hline 7. Sistem pencatatan keuangan belum rapi & 0,153 \\
\hline 8. Proses produksi belum efisien & 0,133 \\
\hline 9. Pengalaman tenaga kerja yang rendah & 0,119 \\
\hline 10. Perusahaan belum memaksimalkan teknologi yang ada & 0,128 \\
\hline Total & 2,592 \\
\hline
\end{tabular}

Dengan memasukkan hasil identifikasi kekuatan dan kelemahan sebagai faktor strategis internal, kemudian memberikan bobot dan rating kepada setiap faktor, maka diperoleh hasil analisis matriks IFE dimana total nilai yang dibobot adalah 2,592. Total nilai bobot tersebut menunjukkan bahwa perusahaan CV. Bintani Poultry Shop Kendari memiliki faktor internal yang tergolong rata-rata, atau kemampuan perusahaan dalam menggunakan kekuatan dan mengurangi kelemahan adalah sedang (rata-rata).

Sejalan dengan penelitian yang dilakukan oleh Rizwan N, $d k k$ (2011) tentang strategi pemasaran peternakan ayam CV. Intan Jaya Abadi Sukabumi bahwa hasil perhitungan dengan matriks IFE diketahui bahwa kemudahaan memperoleh bahan baku diakui sebagai faktor paling penting dalam kegiatan produksi dengan nilai skor 0,384 dan merupakan kekuatan yang dimiliki perusahaan untuk memberikan yang terbaik bagi konsumen. Hal ini terkait dengan adanya komitmen pihak manajemen terhadap mutu produk dengan menyiapkan produk dari hulu ke hilir (nilai skor 0,299). Untuk itu, perusahaan juga memberikan perhatian yang besar terhadap mutu pelayanan konsumen dengan nilai skor 0,289 , yang merupakan kekuatan perusahaan untuk dipertahankan dalam mencapai consumer satisfaction.

Begitu pula dengan penelitian yang dilakukan oleh M. Fajar Trisna Kurniawan, $d k k$ (2013) tentang strategi pengembangan agribisnis peternakan 
ayam petelur di Kabupaten Tabanan, bahwa hasil analisis matriks IFE menunjukkan bahwa faktor internal berupa kekuatan yang berpengaruh sangat penting terhadap pengembangan agribisnis peternakan ayam petelur di Kabupaten Tabanan adalah usaha turuntemurun dengan skor 0,652, karena keluarga sudah terbiasa dengan aktivitas dalam peternakan ayam petelur, sehingga secara teknis sudah dipahami untuk dijadikan modal dalam melanjutkan usaha. Sedangkan, faktor internal berupa kelemahan yang berpengaruh sangat penting adalah keterbatasan jumlah dana dengan skor 0.520. Peternak ayam petelur di Kabupaten Tabanan memiliki keterbatasan jumlah dana untuk bisa memenuhi kebutuhan operasional dalam mengembangkan usaha peternakan.

\section{Analisis Matriks EFE}

Langkah-langkah untuk menyusun matriks EFE hampir sama dengan langkah pada penyusunan matriks IFE, hanya berbeda pada faktor strategis yang dimasukkan pada matriks EFE merupakan peluang (Opportunities) dan ancaman (Threats) yang dihadapi oleh usaha peternakan ayam ras petelur $\mathrm{CV}$. Bintani Poultry Shop Kendari.

Berdasarkan hasil wawancara mendalam dengan pemilik CV. Bintani Poultry Shop Kendari, maka didapatkan total nilai terboboti. Total nilai yang dibobot ini merupakan hasil penjumlahan total dari perkalian bobot dengan rating masing-masing faktor strategis eksternal. Pembobotan dilakukan dengan menggunakan metode Paired Comparison sehingga diperoleh bobot masing-masing faktor. Demikian pula dengan pemberian rating (peringkat) yang dilakukan oleh pemilik perusahaan, sehingga didapatkan nilai terboboti dari faktor-faktor tersebut. Untuk lebih jelasnya dapat dilihat pada Tabel 2.

Tabel 2. Matriks Eksternal Factor Evaluation (EFE)

\begin{tabular}{|c|c|}
\hline Faktor -Faktor Eksternal & Rata-Rata \\
\hline Peluang & Bobot x Rating \\
\hline 1. Permintaan pasar tinggi & 0,479 \\
\hline 2. Peningkatan kesadaran masyarakat & 0,274 \\
\hline 3. Pemasaran mudah dilakukan & 0,148 \\
\hline 4. Dukungan kebijakan pemerintah & 0,153 \\
\hline 5. Ketersediaan bahan baku pakan lokal & 0,294 \\
\hline \multicolumn{2}{|l|}{ Ancaman } \\
\hline 6. Harga pakan dan telur berfluktuasi & 0,507 \\
\hline 7. Kondisi cuaca yang tidak menentu & 0,432 \\
\hline 8. Adanya pesaing baru & 0,309 \\
\hline 9. Pemanfaatan lahan yang semakin sulit & 0,195 \\
\hline 10. Kemudahan pelanggan untuk berpindah & 0,103 \\
\hline Total & 2,895 \\
\hline
\end{tabular}


Dengan memasukkan hasil identifikasi peluang dan ancaman sebagai faktor strategis eksternal, kemudian memberikan bobot dan rating kepada setiap faktor, maka diperoleh hasil analisis matriks EFE dimana total nilai yang dibobot adalah 2,895. Total nilai bobot tersebut menunjukkan bahwa kondisi lingkungan eksternal perusahaan CV. Bintani Poultry Shop Kendari memiliki respon yang cukup tinggi dalam memanfaatkan peluang yang ada dan mengurangi ancaman yang dihadapi perusahaan.

Lebih lanjut tentang penelitian yang dilakukan oleh Rizwan $\mathrm{N}, d k k$ (2011) tentang strategi pemasaran peternakan ayam CV. Intan Jaya Abadi Sukabumi bahwa hasil perhitungan dengan matriks EFE dapat diketahui bahwa adanya hubungan baik dengan pemasok bahan baku (skor 0,379) sebagai kesempatan atau peluang yang dapat diraih oleh CV IJA dalam pengembangan usaha peternakan ayam. Karakteristik yang dibangun adalah kepercayaan dari mitra perusahaan, termasuk konsumen. Selain itu, perusahaan juga menggunakan peluang kemaju-an teknologi (skor 0,353) dan secara umum akan berpengaruh terhadap pengembangan perusaha-an peternakan ayam. Adanya produk pengganti menjadi ancaman besar terhadap perusahaan dengan nilai skor 0,374. Hal ini berkaitan erat dengan daya beli masyarakat terhadap produk daging dan telur ayam. Fluktuasi harga bahan baku (skor 0,360) dan banyaknya pesaing juga merupakan ancaman serius (skor 0,289), baik dari perusahaan dengan skala usaha yang sama maupun semi modern, serta tradisional.

Sedangkan penelitian yang dilakukan oleh M. Fajar Trisna Kurniawan, $d k k$ (2013) tentang strategi pengembangan agribisnis peternakan ayam petelur di Kabupaten Tabanan, menunjukkan bahwa hasil analisis matriks EFAS menunjukkan bahwa faktor eksternal berupa peluang sangat penting adalah ketersediaan pasar dan distribusi pendek dengan skor 0,476. Peternak merasa diuntungkan dengan upaya dari pedagang besar telur ayam yang membeli secara langsung telur ayam tersebut untuk dijual di pasar tradisional maupun kios. Sedangkan, faktor eksternal berupa ancaman sangat penting adalah fluktuasi harga pakan dengan skor 0,524. Kenaikan harga pakan yang tidak diikuti dengan kenaikan harga telur merupakan ancaman utama, selain penyakit ayam, karena peternak ayam dibebankan dari segi biaya untuk menjalankan usaha peternakan ayam petelur tersebut.

\section{B. Strategi Pengembangan Usaha Ayam Ras Petelur \\ 1. Matriks Internal dan Eksternal}

Setelah dilakukan analisis matriks IFE dan EFE, maka tahap selanjutnya adalah menyusun matriks internal-eksternal dan SWOT untuk merumuskan alternatif strategi yang lebih detail sesuai dengan posisi usaha.

Penyusunan matriks IE bertujuan untuk memperoleh strategi ditingkat yang lebih detail. Matriks internal dan eksternal (IE) mengindikasikan 9 sel strategi tetapi umumnya sel tersebut dapat dikelompokkan menjadi tiga strategi utama. Strategi tersebut adalah

1) Strategi pertumbuhan (Growth Strategy), merupakan kondisi pertumbuhan perusahaan (sel 1, 2, 3 dan 5) atau upaya diversifikasi (sel 7 dan 5).

2) Strategi Stabilitas (Stability Strategy) adalah strategi yang diterapkan tanpa mengubah arah strategi yang telah diterapkan (sel 4 dan 5). 
3) Strategi Penciutan (Retrenchment Strategy) adalah usaha memperkecil atau mengurangi usaha yang dilakukan perusahaan (sel 3, 6 dan 9).

Berdasarkan hasil analisis yang dilakukan sebelumnya, total nilai yang dibobot pada matriks IFE adalah 2,592 yang artinya CV. Bintani Poultry Shop Kendari memiliki faktor internal yang berada di atas rata-rata, sedangkan total nilai yang terboboti pada matriks EFE adalah 2,895 yang artinya respon perusahaan terhadap faktor-faktor eksternal yang dihadapinya cukup tinggi.

Total nilai yang dibobot pada matriks IFE dan matriks EFE tersebut kemudian ditetapkan pada matriks IE, sehingga dapat diketahui posisi usaha saat ini, kemudian dirumuskan alternatif strategi yang sesuai dengan posisi usaha di matriks IE. Untuk lebih jelasnya dapat dilihat pada Gambar 1.

\section{TOTAL SKOR IFE}

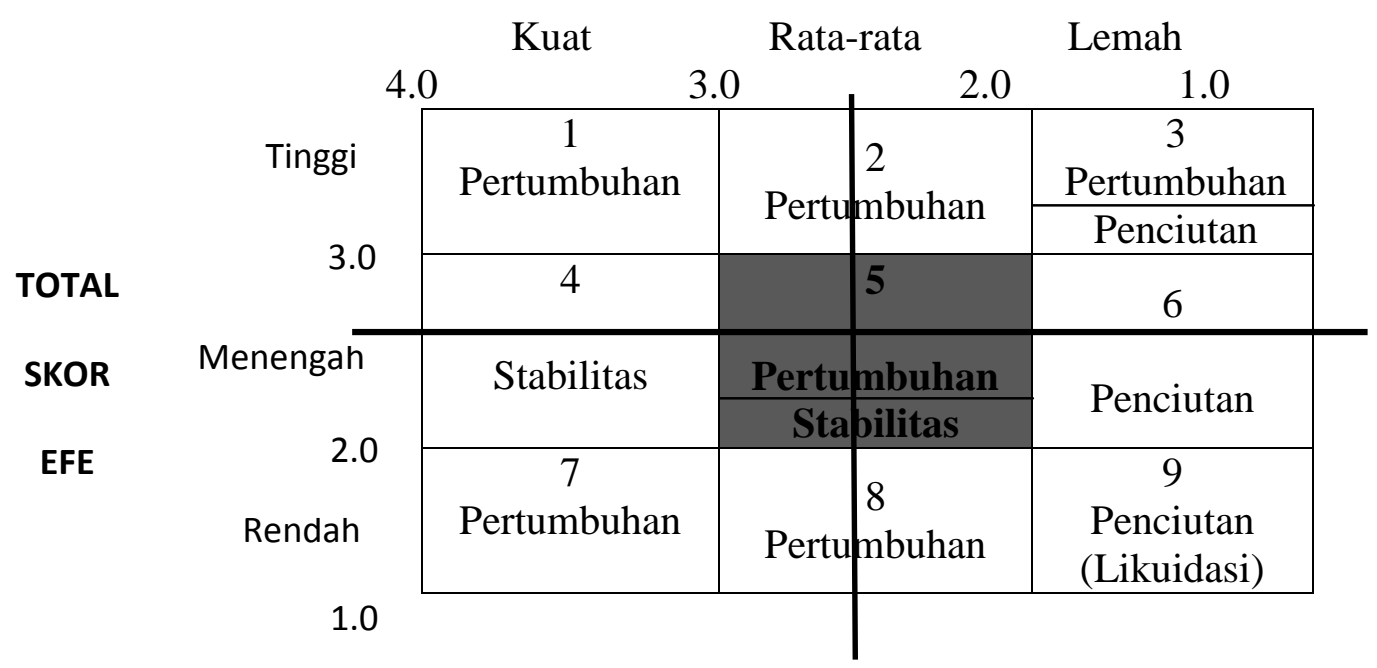

Gambar 1. Matriks Internal-Eksternal CV. Bintani Poultry Shop Kendari

Hasil analisis matriks IE pada Gambar 1, menunjukkan bahwa posisi perusahaan berada pada kotak dikuadran II, yang menggambarkan perusahaan saat ini berada dalam kondisi internal rata-rata dan respon usaha terhadap faktor-faktor eksternal yang dihadapinya cukup tinggi. Inti strategi yang diterapkan oleh CV. Bintani Poultry Shop Kendari adalah stabilitas, tumbuh dan kembangkan.

Hasil peneltiian ini dikukung oleh penelitian Rizwan N, $d k k$ (2011) tentang strategi pemasaran peternakan ayam CV. Intan Jaya Abadi Sukabumi. Dari hasil evaluasi dan analisis yang telah dilakukan, selanjutnya dilakukan analisis internal eksternal yang menghasilkan matriks IE, sehingga diketahui posisi perusahaan untuk mempermudah dalam pemilihan alternatif strategi. Pemetaan posisi perusahaan sangat penting bagi pemilihan alternatif strategi dalam menghadapi persaingan dan perubahan yang terjadi dalam perusahaan peternakan ayam. Dengan total nilai pada matriks internal 2,925, maka $\mathrm{CV}$ IJA memiliki faktor internal yang tergolong sedang atau rataan dalam 
melakukan bisnis peternakan ayam. Total nilai matriks eksternal 3,192 memperlihatkan respon yang diberikan oleh CV IJA kepada lingkungan eksternal tergolong tinggi. Apabila masing-masing total skor dari faktor internal maupun eksternal dipetakan dalam matriks, maka posisi perusahaan saat ini berada di kuadran kedua (Strategi Pertumbuhan). Dengan posisi tersebut, maka strategi tingkat perusahaan yang dapat dikembangkan adalah Intensive Strategy (market penetration, market development dan product development) (David, 2006).

Dipertegas oleh penelitian M. Fajar Trisna Kurniawan, $d k k$ (2013) tentang strategi pengembangan agribisnis peternakan ayam petelur di Kabupaten Tabanan, Usaha yang berada pada sel ini sebaiknya dapat memperbesar pangsa pasar baik melalui peningkatan kuantitas maupun kualitas produk, meningkatkan kerjasama dengan pihak terkait, dan meningkatkan daya saing, disamping itu perusahaan dapat meningkatkan fasilitas produksi dan penguasaan teknologi baik melalui pengembangan sumberdaya internal maupun eksternal dari agribisnis peternakan ayam petelur.

\section{Analisis Matriks SWOT}

Berdasarkan analisis matrik IE, dikatakan bahwa CV. Bintani Poultry
Shop Kendari berada pada kuadran II yang cenderung melakukan konsentrasi melalui strategi intensif, yakni penetrasi pasar. Selain strategi ini, strategi yang dapat dijalankan yaitu strategi integrasi vertikal dengan cara backward integration (mengambil alih fungsi supplier).

Dari strategi yang dihasilkan maka yang dapat mendukung strategi intensif (penetrasi pasar) adalah strategi produksi dengan meningkatkan kapasitas produksi, strategi sumberdaya manusia dengan peningkatan kualitas dan jumlah karyawan, dan strategi pemanfaatan teknologi dalam manajemen pemeliharaan untuk meningkatkan produksi dan pemasaran untuk melakukan promosi. Sedangkan yang dapat digolongkan ke strategi intergratif adalah melakukan dipengembangan usaha dengan usaha jenis ternak lainnya seperti usaha penggemukan sapi potong.

Dalam mengembangkan usaha CV. Bintani Poultry Shop Kendari, faktor-faktor internal dan eksternal tersebut ditabulasikan pada matriks analisis SWOT. Matriks analisis SWOT dalam merumuskan strategi pengembangan usaha peternakan ayam ras petelur CV. Bintani Poultry Shop Kendari tersebut dapat dilihat pada Gambar 2. Adapun strategi-strateginya adalah: 


\begin{tabular}{|c|c|c|}
\hline Faktor Eksternal & $\begin{array}{l}\text { Strength }-\boldsymbol{S} \\
\text { 1. Ketersedian faktor } \\
\text { produksi secara kontinyu } \\
\text { 2. Memiliki lahan yang luas. } \\
\text { 3. Kualitas telur yang segar. } \\
\text { 4. Hubungan perusahaan } \\
\text { dengan konsumen/ } \\
\text { pelanggan. } \\
\text { 5. Citra perusahaan terhadap } \\
\text { lembaga keuangan baik }\end{array}$ & $\begin{array}{l}\text { Weakness - } \boldsymbol{W} \\
\text { 1. Produksi belum } \\
\text { memenuhi permintaan } \\
\text { pelanggan } \\
\text { 2. Sistim pencatatan } \\
\text { laporan keuangan } \\
\text { belum rapi } \\
\text { 3. Proses produksi } \\
\text { belum efisien, } \\
\text { diakibatkan karyawan } \\
\text { yang belum } \\
\text { professional } \\
\text { 4. Promosi belum } \\
\text { maksimal } \\
\text { 5. Perusahaan belum } \\
\text { memaksimalkan } \\
\text { teknologi yang ada }\end{array}$ \\
\hline $\begin{array}{l}\text { Opportunities - } \boldsymbol{O} \\
\text { 1. Permintaan pasar tinggi. } \\
\text { 2. Peningkatan kesadaran } \\
\text { masyarakat } \\
\text { 3. Pemasaran mudah dilakukan } \\
\text { 4. Dukungan kebijakan } \\
\text { pemerintah } \\
\text { 5. Ketersediaan bahan baku }\end{array}$ & $\begin{array}{l}\text { Strategi SO } \\
\text { Peningkatan kapasitas } \\
\text { Produksi } \\
(\mathrm{S} 1, \mathrm{~S} 2, \mathrm{~S} 3, \mathrm{~S} 4, \mathrm{~S} 5, \mathrm{O} 1, \mathrm{O} 2 \\
\text {,O3,O4, O5) }\end{array}$ & $\begin{array}{l}\text { Strategi WO } \\
\text { Peningkatan kualitas dan } \\
\text { jumlah karyawan } \\
\text { (W1,W2, W3, } \\
\mathrm{O} 1, \mathrm{O} 2, \mathrm{O} 3, \mathrm{O} 4)\end{array}$ \\
\hline $\begin{array}{l}\text { Threats - T } \\
\text { 1. Harga pakan dan telur } \\
\text { berfluktuasi } \\
\text { 2. Kondisi cuaca yang tidak } \\
\text { menentu } \\
\text { 3. Adanya pesaing baru } \\
\text { 4. Menyempit lahan dan } \\
\text { pertumbuhan penduduk } \\
\text { 5. Kemudahan pelanggan untuk } \\
\text { berpindah }\end{array}$ & $\begin{array}{l}\text { Strategi ST } \\
\text { Melakukan pengembangan } \\
\text { usaha jenis ternak lainnya } \\
(\mathrm{S} 1, \mathrm{~S} 2, \mathrm{~S} 3, \mathrm{~S} 4, \mathrm{~S} 5, \mathrm{~T} 1, \mathrm{~T} 2 \text {, } \\
\mathrm{T} 3, \mathrm{~T} 5)\end{array}$ & $\begin{array}{l}\text { Strategi WT } \\
\text { Pemanfaatan teknologi } \\
\text { dalam pemeliharaan } \\
\text { ayam ras petelur dan } \\
\text { pemasaran } \\
(\mathrm{W} 4, \mathrm{~W} 5, \mathrm{~T} 3, \mathrm{~T} 4, \mathrm{~T} 5)\end{array}$ \\
\hline
\end{tabular}

Gambar 2. Matriks SWOT pada CV. Bintani Poultry Shop Kendari

\section{Analisis Matriks QSPM}

Pemilihan strategi prioritas ini dilakukan oleh pemilik dari usaha peternakan ayam ras petelur $\mathrm{CV}$. Bintani Poultry Shop Kendari melalui wawancara yang mendalam sehingga dihasilkan urutan prioritas strategi yang harus diterapkan. Hasil yang diperoleh adalah sebagai berikut :

a. Peningkatan kapasitas produksi dengan skor 6,146. Peningkatan produksi dapat dilakukan dengan penambahan kandang, karena pemilik masih memiliki lahan kosong yang dapat dimanfaatkan.

b. Peningkatan kualitas dan jumlah karyawan dengan skor 5,375. Peningkatan kualitas karyawan dapat dilakukan melalui pemberian pelatihan khusus tentang pengetahuan teknis dalam beternak ayam ras petelur

c. Pemanfaatan teknologi dalam pemeliharaan ayam ras petelur dengan skor 5,303. Pemanfaatan teknologi dalam pemeliharaan ayam 
ras petelur dapat dilakukan dengan membangun kandang permanen dengan sistem teknologi modern, sehingga sanitasi kandang dapat terjaga setiap saat.

d. Melakukan pengembangan usaha jenis ternak lainnya 4,220. Pengembangan usaha yang dapat dilakukan adalah penggemukan sapi, karena pemilik masih memiliki lahan yang cukup luas dan dapat dimanfaatkan, hal ini pula didukung oleh permintaan daging yang sapi cukup tinggi.

Hasil analisis QSPM pada penelitian yang dilakukan oleh M. Fajar Trisna Kurniawan, dkk (2013) tentang strategi pengembangan agribisnis peternakan ayam petelur di Kabupaten Tabanan, diperoleh gambaran bahwa nilai TAS (total attractives score) dari strategi pengembangan agribisnis peternakan ayam petelur yang menunjukkan nilai tertinggi sampai terendah adalah sebagai berikut :

1. Peningkatan pangsa pasar untuk meraih posisi market leader melalui kebijakan dari pemerintah daerah dan perusahaan yang terkait, dengan skor 5,194. Itu berarti bahwa strategi pengembangan agribisnis peternakan ayam petelur menjadi pilihan utama.

2. Strategi peningkatan produksi melalui pengendalian dan pengawasan terhadap hama atau penyakit ternak agar usaha peternakan bisa berkelanjutan menjadi pilihan kedua dengan skor 4,661 .

3. Strategi alternatif dengan memberikan jaminan dalam permodalan dan mengoptimalkan petugas lapangan menjadi pilihan ketiga dengan skor 4,560 .

4. Strategi mengoptimalkan modal usaha dan meningkatkan kemampuan dalam pengembangan agribisnis menjadi pilihan keempat dengan skor 4,194.

\section{KESIMPULAN}

Dari analisis SWOT dan analisis QSPM maka rumusan strategi yang dihasilkan adalah sebagai berikut :

1. Strategi peningkatan kapasitas Produksi dengan skor 6,146. Peningkatan produksi dapat dilakukan dengan penambahan kandang, karena pemilik masih memiliki lahan kosong yang dapat dimanfaatkan sehingga populasi ayam dapat meningkat.

2. Strategi peningkatan kualitas dan jumlah karyawan dengan skor 5,375. Peningkatan kualitas karyawan dapat dilakukan melalui pemberian pelatihan khusus tentang pengetahuan teknis dalam beternak ayam ras petelur.

3. Strategi pemanfaatan teknologi dalam pemeliharaan ayam ras petelur dengan skor 5,303. Pemanfaatan teknologi dalam pemeliharaan ayam ras petelur dapat dilakukan dengan membangun kandang permanen dengan sistem teknologi modern, sehingga sanitasi kandang dapat terjaga setiap saat.

4. Strategi pengembangan usaha jenis ternak lainnya 4,220. Pengembangan usaha yang dapat dilakukan adalah penggemukan sapi, karena pemilik masih memiliki lahan yang cukup luas dan dapat dimanfaatkan, hal ini pula didukung oleh permintaan daging yang sapi cukup tinggi. 


\section{DAFTAR PUSTAKA}

Abidin. Z, 2003. Ayam Ras Petelur. PT. Agromedia Pustaka, Jakarta.

Cahyono, B. 2002. Ayam Buras Pedaging. PT. Penebar Swadaya, Jakarta.

David, F.R. 2006. Strategic Management. Prentice Hall International Inc., New Jersey.

Dinas Pertanian, Perkebunan, Peternakan dan Kehutanan Kota Kendari. 2010. Laporan Tahunan. Dinas Pertanian, Perkebunan, Peternakan dan Kehutanan Kota Kendari. Kendari.

Dinas Pertanian Provinsi Sulawesi Tenggara. 2011. Statistik Peternakan Tahun 2006-2010. Dinas Pertanian Provinsi Sulawesi Tenggara. Kendari.

M. Fajar Trisna Kurniawan, Dwi Putra Darmawan), NW. Sri Astiti. Strategi Pengembangan Agribisnis Peternakan Ayam Petelur di Kabupaten Tabanan. Program studi magister agribisnis, program pascasarjana, universitas udayana. Jurnal Manajemen Agribisnis vol. 1 no. 2 tahun 2013 ISSN: 23550759

Rangkuti, F., 2006. Analisis SWOT, Tehnik Menbedah Kasus Bisnis. PT. Gramedia Pustaka Utama. Jakarta.

Rizwan Nazaruddin, Suryahadi dan Ma'mun Sarma, 2011. Analisis Strategi Pemasaran Peternakan Ayam CV Intan Jaya Abadi Sukabumi. Jurnal Manajemen IKM (125-132) ISSN 2085-8418 Vol. 6 No. 2.

Saragih, B., 2001. Penyuluhan Pertanian. Penerbit Yayasan Pengembangan Sinar Tani. Jakarta.

Wijaya, K dan Abdullah, S. 2003. Peluang Bisnis Ayam Ras dan Buras. PT. Penebar Swadaya. Jakarta. 